\title{
Photochemical Transformations of Dichloroacetamide Safeners
}

\author{
Andrew E. Kral,$^{{ }^{*}}$ Nicholas C. Pflug, ${ }^{{ }^{*}}$ Monica E. McFadden,${ }^{\S}$ Gregory H. LeFevre, ${ }^{\S \star}$ \\ John D. Sivey, " and David M. Cwiertny ${ }^{\S \dagger \$ ¥ * * *}$
}

${ }^{\S}$ Department of Civil \& Environmental Engineering, 4105 Seamans Center for the Engineering Arts and Sciences, University of Iowa, Iowa City, IA, 52242

${ }^{\mathfrak{f}}$ Department of Chemistry, E331 Chemistry Building, University of Iowa, Iowa City, IA, United States;

${ }^{\#}$ Department of Chemistry, Towson University, 543 Smith Hall, Towson, Maryland 21252, United States

†Department of Chemical \& Biochemical Engineering, 4133 Seamans Center for the Engineering Arts and Sciences, University of Iowa, Iowa City IA, 52242

IIHR-Hydroscience \& Engineering, 100 C. Maxwell Stanley Hydraulics Laboratory University of Iowa, Iowa City, IA 52242

${ }^{\sharp}$ Center for Health Effects of Environmental Contamination, 455 Van Allen Hall, University of Iowa, Iowa City, IA 52242

${ }^{\epsilon}$ Public Policy Center, 310 South Grand Ave, 209 South Quadrangle, University of Iowa, Iowa City, IA 52242

*Equal contribution in lead authorship

${ }^{* *}$ Corresponding Author:

David M. Cwiertny

Email: david-cwiertny@uiowa.edu; Phone: 319-335-1401

Department of Civil and Environmental Engineering

4136 Seamans Center

Iowa City, IA 52242

Prepared for Environmental Science and Technology

May 15, 2019

26 Pages, 22 Figures and 5 Tables

Supporting information contains additional experimental details related to the reagents used in all experiments, analytical methods, methods related to the measurement of quantum yield, and assessing the role of reactive oxygen species and triplet dissolved organic matter in indirect photolysis experiments. Additional results from photolysis studies and product characterization are also presented. 


\section{Materials and Methods}

Chemicals All chemicals were used as received. The dichloroacetamide safeners used in photolysis experiments were benoxacor (Fluka, 99.4\%, CAS 98730-04-2), dichlormid (TCI America, $>97.0 \%$, CAS 37764-25-3), furilazole (Fluka, 99.6\%, CAS 121776-33-8), and AD-67 (CAS 71526-07-3). Technical grade AD 67 was donated from Nanjing Essence Fine-Chemical Co. All experiments were conducted in buffered solutions of deionized water (Millipore, Q-Grad 2) and potassium phosphate buffer (RPI). The $\mathrm{pH}$ was adjusted using hydrochloric acid (Fisher Scientific, ACS grade) and sodium hydroxide (Fisher Scientific, ACS grade, 1310-73-2). Acetonitrile (Fisher Scientific, Optima grade) was used as a solvent for stock solution preparation, in limited photolysis experiments, and as a liquid phase during HPLC analysis. Deionized water (Millipore, Q-Grad 2) was used to prepare buffered solutions and also used as a HPLC mobile phase. Chloroform (Fisher Scientific, ACS grade) was used as the non-polar phase during liquid-liquid extraction to isolate benoxacor photoproducts. An actinometer system of 4nitroanisole (Sigma) and pyridine (Fischer Scientific) was used to calculate benoxacor quantum yield. Indirect photolysis experiments used Pahokee Peat humic acid (IHSS), Suwanee River humic acid (IHSS), potassium phosphate (RPI), sodium nitrate (RPI), and sodium nitrite (RPI).

Direct Photolysis Experimental Details. For direct photolysis using the 1000W Newport Xe arc lamp, the light beam was passed through an AM 1.5 filter, a recirculated water filter to remove IR radiation, and a $305 \mathrm{~nm}$ long-pass filter. Lamp irradiance (output over 300$400 \mathrm{~nm}=8.8 \times 10^{-3} \mathrm{~W} / \mathrm{cm}^{2}$; Figure S2a) was monitored using an ILT 950 spectroradiometer (International Light Technologies, Peabody, MA). For idealized aquatic environments, we used matrices of $5 \mathrm{mM}$ potassium phosphate buffer adjusted to $\mathrm{pH} 5,7$, or 9 with $\mathrm{HCl}$ or $\mathrm{NaOH}$. Select experiments were also conducted in Iowa River water first passed through a $25 \mu \mathrm{m}$ Whatman filter paper. Concentrated safener stock solutions $(10 \mathrm{mM})$ were freshly prepared in acetonitrile and stored in a freezer $\left(\sim-18{ }^{\circ} \mathrm{C}\right)$ until use. Stock solutions were then diluted in appropriate buffer (resulting in $0.1 \%$ residual acetonitrile by volume) to produce an initial aqueous safener concentration of $10 \mu \mathrm{M}$ for direct photolysis experiments (corresponding to AD$67=2.52 \mathrm{mg} / \mathrm{L}$; furilazole $=2.78 \mathrm{mg} / \mathrm{L}$; benoxacor $=2.60 \mathrm{mg} / \mathrm{L}$; dichlormid $=2.08 \mathrm{mg} / \mathrm{L}$ ). These concentrations are higher than those in natural surface waters, but were necessary to accurately monitor reaction progress and identify photoproducts during HPLC-DAD analysis. Photolyzed safener solutions were continuously mixed in a water-jacketed borosilicate reaction vessel (37 mm inner diameter $\times 67 \mathrm{~mm}$ depth, total volume $\sim 50 \mathrm{~mL}$; Chemglass) fixed at $25^{\circ} \mathrm{C}$ via a recirculating water bath.

In addition to these experiments conducted in buffered aqueous solutions, some experiments were conducted in acetonitrile to determine the role of water in photoproduct formation. These experiments were also photolyzed under the $1000 \mathrm{~W}$ Xe lamp in water jacketed reaction vessels, where 100 or $500 \mu \mathrm{M}$ of benoxacor was prepared in $20 \mathrm{~mL}$ acetonitrile and photolyzed. To test the aqueous stability of photoproducts generated in acetonitrile, an aliquot of this reaction mixture (generated after $1 \mathrm{~h}$ of irradiation) was diluted into $5 \mathrm{mM} \mathrm{pH} 7$ phosphate buffer and either stored in the dark or placed back under the lamp for continued photolysis. 
Quantum Yield Calculation To calculate the quantum yield $(\Phi)$ of benoxacor, we used a chemical PNA-pyridine actinometer system to relate a well-defined quantum yield (i.e., the quantum yield of the PNA-pyridine system) to the quantum yield of our compound of interest (S-1):

$$
\Phi_{c}=\left(\Phi_{P N A-p y r}\right)\left(\frac{k_{c} \sum_{300 n m}^{400 n m}\left(\varepsilon_{\lambda, c} \times L_{\lambda}\right)}{k_{P N A-p y r} \sum_{300 n m}^{400 n m}\left(\varepsilon_{\lambda, P N A-p y r} \times L_{\lambda}\right)}\right)
$$

where $\Phi$ is the quantum yield; $\mathrm{k}$ is the first-order rate constant $\left(\mathrm{min}^{-1}\right) ; \varepsilon$ is the molar absorptivity $\left(\mathrm{M}^{-1} \mathrm{~cm}^{-1}\right)$; and $\mathrm{L}$ is the irradiance $\left(\mathrm{W} \mathrm{m}^{-2} \mathrm{~nm}^{-1}\right)$ of the $1000 \mathrm{~W}$ Xe lamp at a given wavelength (note: subscripts c and PNA-pyr denote the compound of interest and the actinometer system, respectively). ${ }^{1-3}$ First order rate constants were calculated for benoxacor in $\mathrm{pH} 7$ potassium phosphate buffer and the PNA/pyrindine solution (10 $\mu \mathrm{M}$ PNA, $20 \mathrm{mM}$ pyridine) in deionized millipore water $\left(0.074 \mathrm{~min}^{-1}\right.$ and $0.070 \mathrm{~min}^{-1}$, respectively) using an integrated first order rate law (Figure S4). Lamp irradiances $\left(L_{\lambda}\right)$ were measured immediately after each experiment, and in order to minimize and accurately quantify differences in irradiance between trials, solutions were photolyzed shortly after one another. Molar absorptivity $(\varepsilon)$ found using Beer's Law (S-2):

$$
A=\varepsilon b c \quad(\mathrm{~S}-2)
$$

where $A$ is absorbance (measured with Thermo Scientific Genesys 10uv), $b$ is the path length of the quartz cuvette $(1 \mathrm{~cm})$, and $c$ is the concentration of benoxacor $(10 \mu \mathrm{M})$. A molar absorptivity was calculated for each wavelength $(\lambda)$ across the range range $300 \mathrm{~nm}-400 \mathrm{~nm}$. A molar absorptivity for PNA/pyridine at each wavelength in this range was provided by Laszakovits et al. ${ }^{3}$ The quantum yield of the PNA/pyridine system was found using the concentration of pyridine $(20 \mathrm{mM})$ and the equation provided by Laszakovits et al. ${ }^{3}$ :

$$
\Phi_{P N A-p y r}=0.29[p y r]+0.00029
$$

Indirect Photolysis Experiments. Experiments were conducted in a SunTest CPS+ solar simulator with an irradiance setting of $750 \mathrm{~W} / \mathrm{m}^{2}$ (Atlas Material Testing Technology, Mount Prospect, IL; an example irradiance spectrum is provided in Figure S2c), equivalent to approximately three times that of the sun at the Earth's surface. Solutions were photolyzed in quartz tubes with cork stoppers held at an angle of $30^{\circ}$. Reaction matrices for indirect photolysis experiments were the same as those for direct photolysis experiments except for the addition of photosensitizers. Stock solutions of sodium nitrate and sodium nitrite were prepared in deionized water. Stock solutions of humic acids were prepared in deionized water adjusted to $\mathrm{pH} 12$ to ensure complete solubility. After dissolution, the stock solution was readjusted to $\mathrm{pH} 7$.

Use of Selective ROS Quenchers in Indirect Photolysis Systems. For singlet oxygen $\left({ }^{1} \mathrm{O}_{2}\right)$, we photolyzed furilazole in $10 \mathrm{mg} / \mathrm{L}$ Pahokee Peat Humic Acid in the presence of $10 \mathrm{mM}$ sodium azide, a known ${ }^{1} \mathrm{O}_{2}$ quencher. ${ }^{4,5}$ Radical quenching experiments were conducted for both $\mathrm{NO}_{3}{ }^{-}$and $\mathrm{NO}_{2}{ }^{-}$systems in the presence of $50 \mathrm{mM}$ isopropyl alcohol (IPA). IPA is a well-known ${ }^{\circ} \mathrm{OH}$ quencher, but it is generally unselective and can quench other radical species (i.e., NO*). ${ }^{2}$

Detailed Analytical Methods. Liquid chromatography high-resolution mass spectrometry (LC-HRMS) data was collected for benoxacor photolysis reaction mixtures using a Waters Premier Q-TOF instrument, an Agilent Zorbax Eclipse XDB-C18 column, and an 
acetonitrile/water gradient elution (see Table S2) with the addition of $0.1 \%$ formic acid solution using a reference standard of leu-enkaphalin and positive electrospray ionization (ESI). Isolated benoxacor photolysis product HRMS data was gathered on the same instrument via direct injection using a leu-enkaphalin reference standard and ESI over a range of 120-1000 Da. All ESI data was collecting using the following instrument parameters: ESI capillary: $2.8 \mathrm{kV}$, sampling cone: $35 \mathrm{~V}$, source temperature: $110^{\circ} \mathrm{C}$, desolvation temperature: $350{ }^{\circ} \mathrm{C}$, cone gas flow: $30 \mathrm{~L} / \mathrm{h}$, desolvation gas flow: $700 \mathrm{~L} / \mathrm{h}$.

Additional product analysis was conducted by gas chromatography high-resolution mass spectrometry (GC-HRMS) using a Waters GCT Premier and a $30 \mathrm{~m}$ DB-5MS column with a 0.25 diameter. The GC temperature program began at $50{ }^{\circ} \mathrm{C}$ and held for $1 \mathrm{~min}$ before ramping at $20{ }^{\circ} \mathrm{C} / \mathrm{min}$ to a final temperature of $320^{\circ} \mathrm{C}$ that was then held for $5 \mathrm{~min}$. Detection was conducted in electron ionization mode with an electron energy $(\mathrm{eV})$ of 70.0 and a source temperature of $200{ }^{\circ} \mathrm{C}$.

For product structural elucidation via NMR, ${ }^{1} \mathrm{H}$ NMR, Heteronuclear Single Quantum Coherence (HSQC), and Heteronuclear Multiple Bond Correlation (HMBC) spectra were recorded using a Bruker AVANCE-600 spectrometer using $\mathrm{CDCl}_{3}$ or $\mathrm{CD}_{3} \mathrm{CN}$ as the solvent. Chemical shift values were referenced to the residual solvent signals $\left(\delta_{\mathrm{H}} / \delta_{\mathrm{C}}, 7.26 / 77.2\right.$ or 1.94/118.3, respectively). All NMR data were processed using Bruker Topspin 3.5 software (Bruker Daltonics Inc., Billerica, MA).

The HSQC experiment was used to provide one-bond proton-carbon correlations. This method relies on indirect detection of ${ }^{13} \mathrm{C}$ nuclei by observing their effect on the more sensitive proton nuclei to which they are coupled (inverse detection). This procedure began by tuning the probe followed by obtaining a well-shimmed proton spectrum. The proton pulse calibration was carried out using the pulse program "zg," from which the parameters P0 ( $90^{\circ}$ pulse), P1 ( $90^{\circ}$ pulse), and P2 ( $180^{\circ}$ pulse) were determined. The following parameters were set with the pulse program "hsqcetgp": D1 = $4 \mathrm{sec}, \mathrm{D} 2[1 /(2 \mathrm{xJXH})]=3.3 \mathrm{msec}$ (if experiment is optimized for $\mathrm{J}=$ $150 \mathrm{~Hz}$ ), D13 $=3 \mu \mathrm{sec}, \mathrm{DS}=4, \mathrm{NS}=16, \mathrm{TD}=8 \mathrm{k}$. After acquisition, the commands $\mathrm{FT}$ and $\mathrm{MC}$ were entered in order to observe signals for protons bound to ${ }^{13} \mathrm{C}$ atoms and to determine signal intensity to predict the number of scans required for the HSQC experiment. The HSQC experiment was then conducted using the pulse program "hsqcetgp" with the following parameters: $\mathrm{DS}=96, \mathrm{TD}=2 \mathrm{k}, \mathrm{NS}=$ multiple of $8, \mathrm{RG}=16 \mathrm{k}$, $\mathrm{TD}(\mathrm{F} 1$ dimension $)=256$ or 512 , $\mathrm{SI}=1 \mathrm{k}, \mathrm{SFO} 1(\mathrm{~F} 1$ dimension $)=150.92 \mathrm{MHz}, \mathrm{ND} 0=2, \mathrm{IN} 0=15 \mu \mathrm{sec}, \mathrm{O} 2 \mathrm{P}=80$. The parameter mode was set to $2 \mathrm{D}$ and the acquisition was initiated by typing $\mathrm{zg}$.

The HMBC experiment was used to provide long-range two- and three-bond ${ }^{1} \mathrm{H}^{13} \mathrm{C}$ correlations. The experiment used the pulse program "hmbcgplpndqf" and the parameters and procedures were nearly identical to those of HSQC, with the exception that IN0 $=13 \mu \mathrm{sec}$, and $\mathrm{O} 2 \mathrm{P}=100$. The D6 parameter was used to optimize the experiment for the desired J-value. In most cases, a typical value of $8 \mathrm{~Hz}$ was used, which corresponds to a D6 value of $60 \mathrm{msec}$. 
Table S1. Common dichloroacetamide safeners and chloroacetamide herbicides. Also provided for safeners is their corresponding active ingredient and the primary crop to which they are applied.

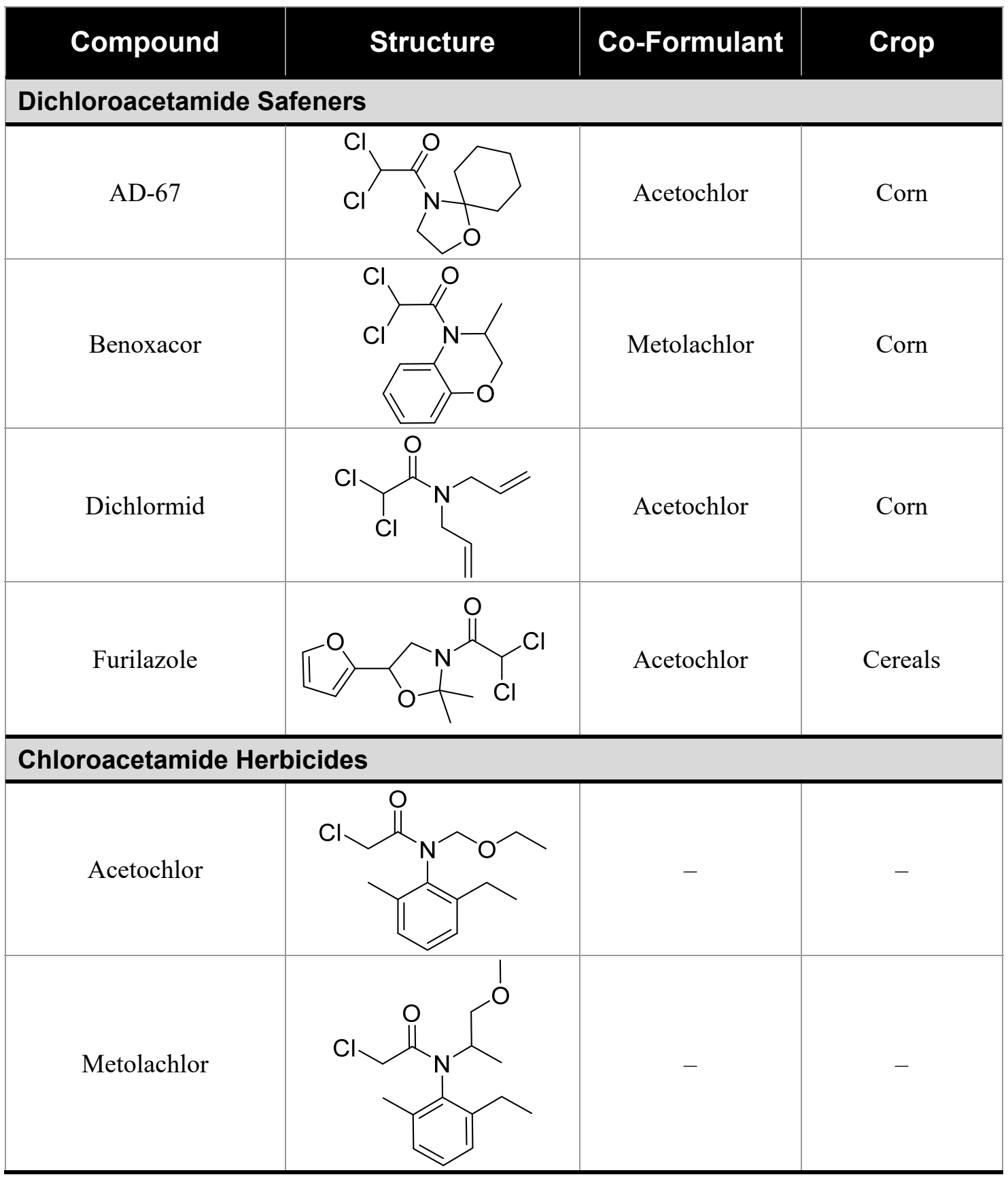


Table S2. HPLC-DAD solvent gradient used for analysis of dichloroacetamide safeners.

\begin{tabular}{|c|c|c|}
\hline Time (min) & \% Composition ACN & \% Composition DI $\mathbf{H}_{\mathbf{2}} \mathbf{O}$ \\
\hline 0 & 25 & 75 \\
\hline 11 & 80 & 20 \\
\hline 12 & 25 & 75 \\
\hline 15 & 25 & 75 \\
\hline
\end{tabular}




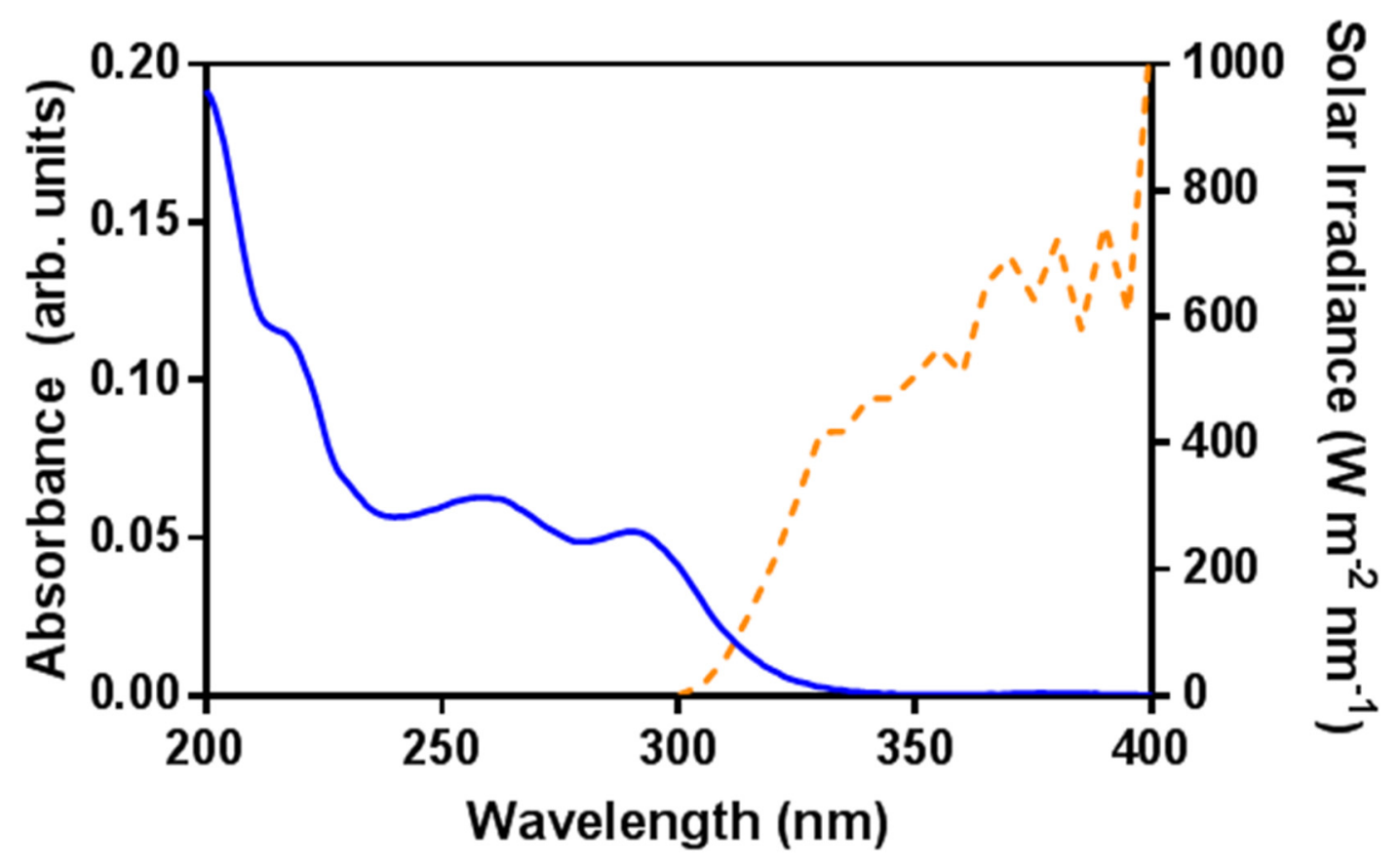

Figure S1. UV/visible absorbance of benoxacor relative to solar spectrum. The solid blue line shows UV-vis absorbance spectrum of benoxacor. The solar irradiance available at the earth's surface (dashed orange line) is provided for comparison [ASTM reference spectra G17303(2012) ]. ${ }^{6}$ Absorbance maxima for benoxacor exist at 216, 258, and $290 \mathrm{~nm}$. 


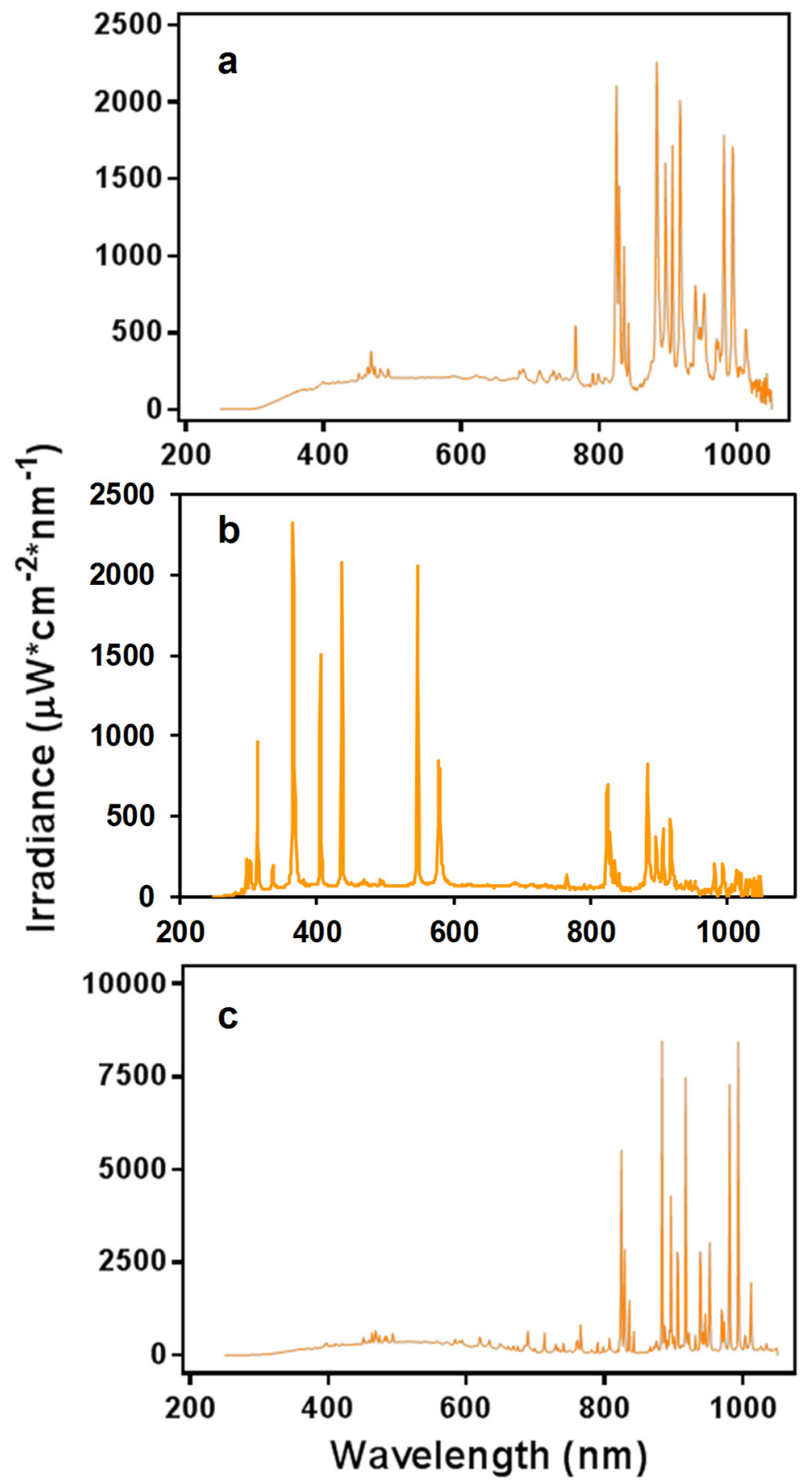

Figure S2. Irradiance spectra of (a) $1000 \mathrm{~W}$ Newport Xe lamp equipped with $305 \mathrm{~nm}$ cut-on filter and 1.5 AM filter, (b) $250 \mathrm{~W}$ Newport XeHg lamp equipped with $250 \mathrm{~nm}$ cut-on filter, and (c) a SunTest CPS+ solar simulator operated at $750 \mathrm{~W} \mathrm{~m}^{-2}$ with an Atlas UV Suntest filter. Output over $300-400 \mathrm{~nm}$ is $8.8 \times 10^{-3} \mathrm{~W} \mathrm{~cm}^{-2}$ and $1.3 \times 10^{-2} \mathrm{~W} \mathrm{~cm}^{-2}$ in (a) and (c), respectively, while the output from $250-400 \mathrm{~nm}$ is $1.7 \times 10^{-2} \mathrm{~W} \mathrm{~cm}^{-2}$ in (b). 


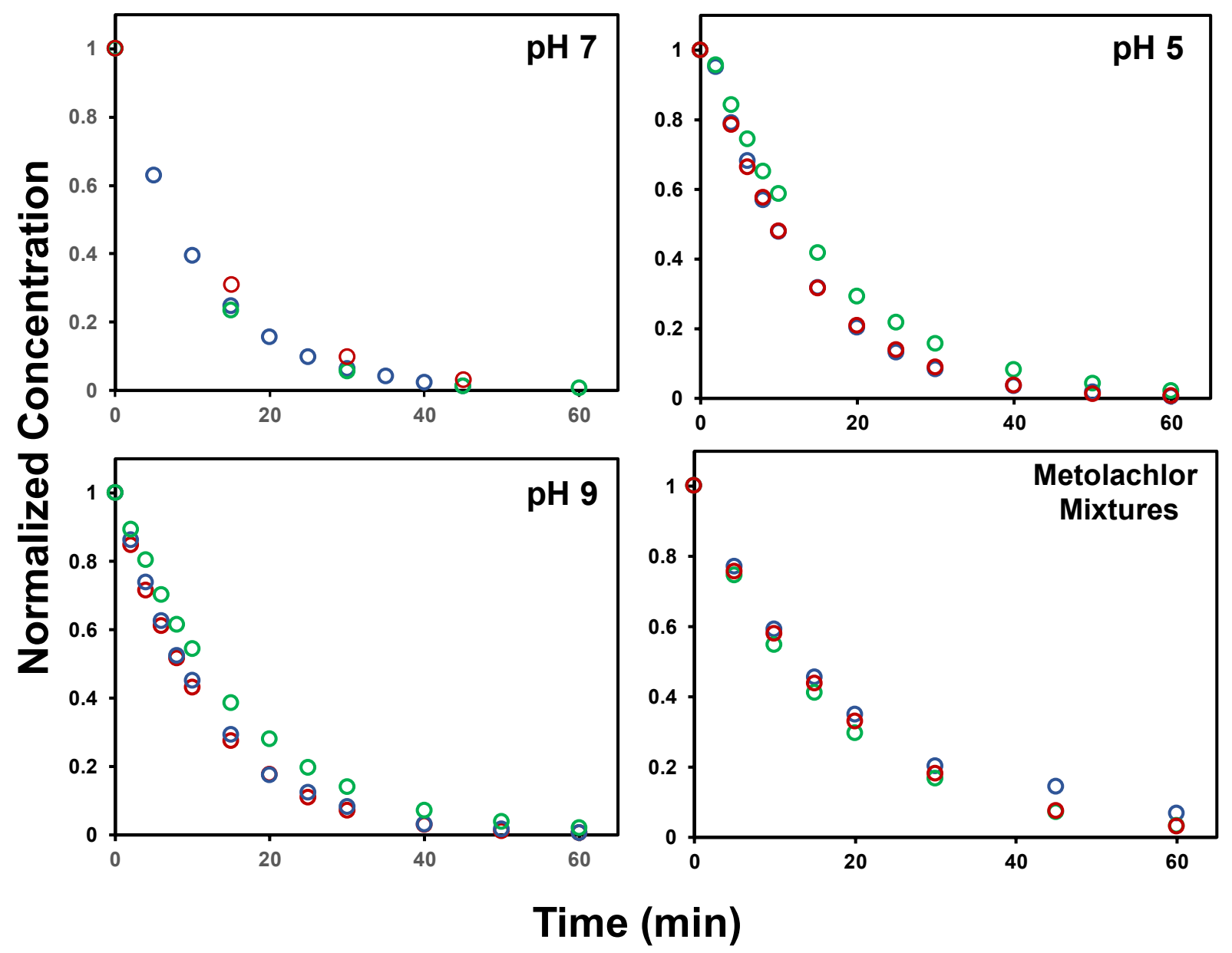

Figure S3. Triplicate experimental data for the direct photolysis of benoxacor at $\mathrm{pH} 5,7$ and 9 (as indicated). Also provided are data from direct photolysis experiments conducted with mixtures of benoxacor and metolachlor at $\mathrm{pH} 7$ containing $10 \mu \mathrm{M}$ benoxacor and either 0,10 , or $100 \mu \mathrm{M}$ of metolachlor (blue, red and green data points, respectively). Generally, our experimental photolysis data yielded time-dependent concentration values that varied within 5\% standard deviation for replicates collected at a given time point. Model fitting to each set of time course data produced corresponding pseudo-first-order rate coefficients ( $k_{\mathrm{obs}}$ values) that varied within $15 \%$ standard deviation across replicate experimental trials. 
a)
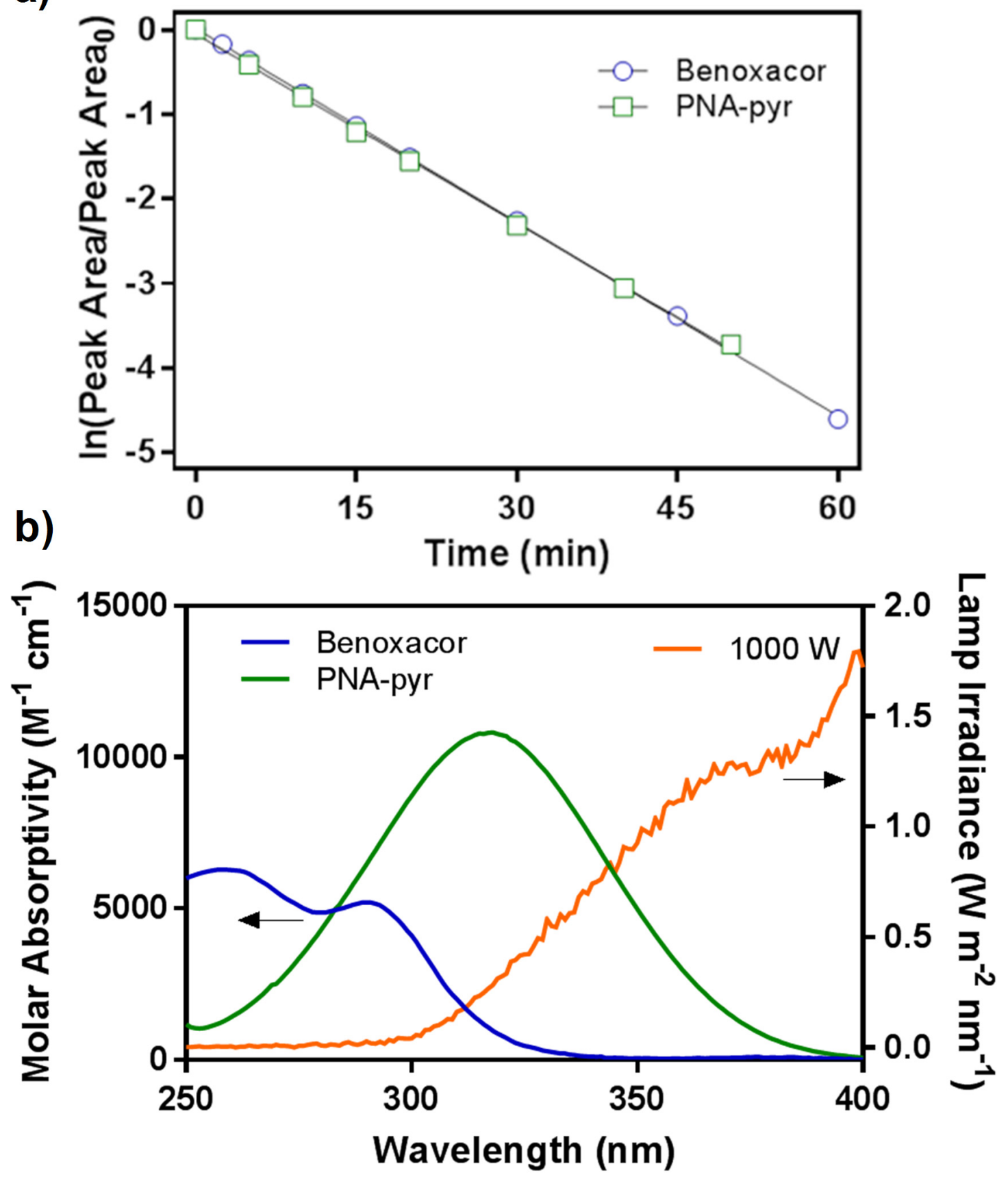

Figure S4. (a) Semi-log plots of concentration versus time with linear regression model fits for photolysis of PNA-pyr actinometer $\left(\mathrm{R}^{2}=0.999\right)$ and benoxacor in $5 \mathrm{mM} \mathrm{pH} 7$ potassium phosphate buffer $\left(\mathrm{R}^{2}=0.999\right)$. (b) PNA-pyr actinometer and benoxacor molar absorptivity (left arrow, left y-axis) compared to irradiance of $1000 \mathrm{~W}$ Xe lamp with $305 \mathrm{~nm}$ cut-on filter and AM 1.5 filter (right arrow, right y-axis). Quantum yield for the direct photolysis of benoxacor was calculated across 300 to $400 \mathrm{~nm}$. 


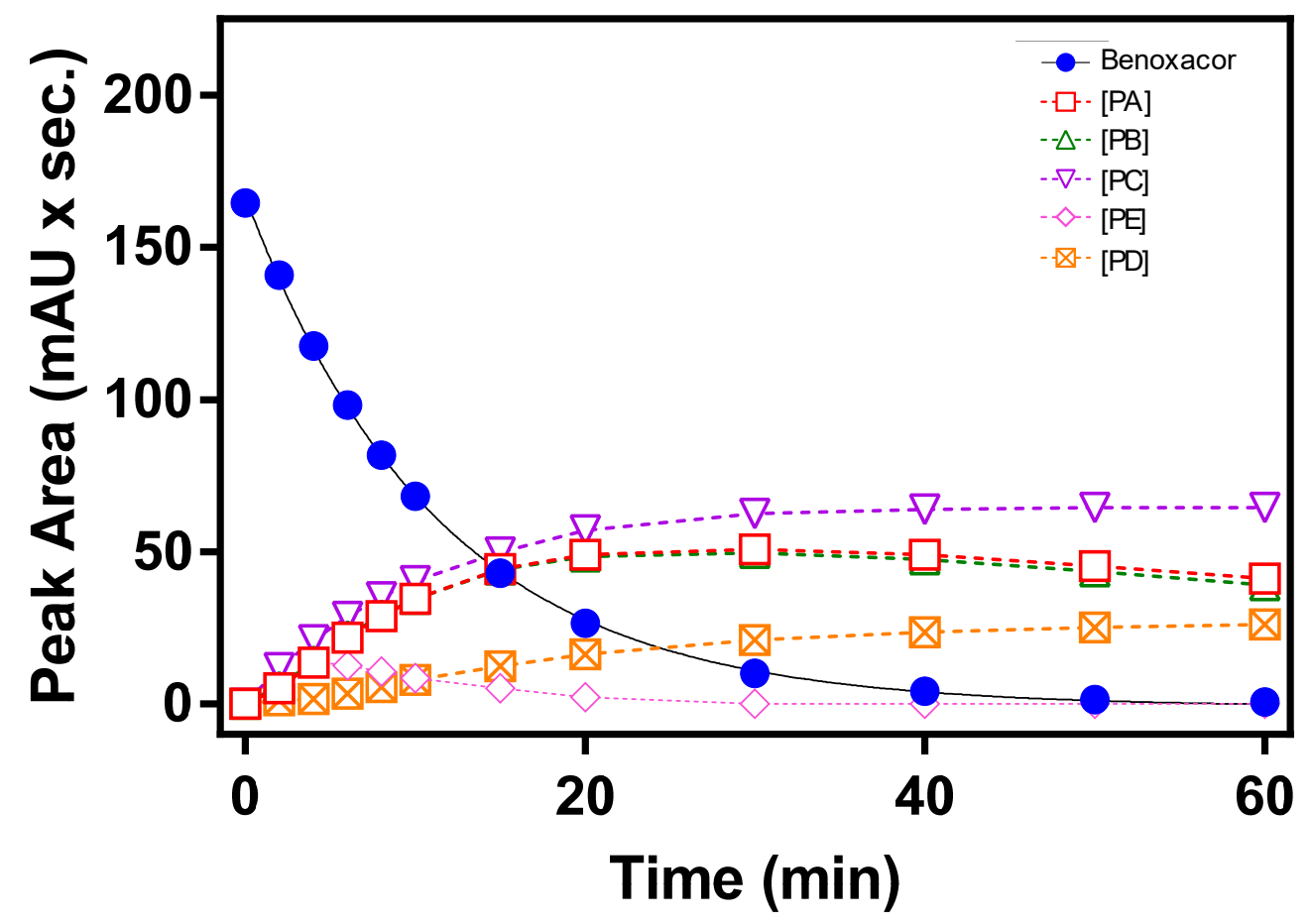

Figure S5. Benoxacor photolysis in filtered $(25 \mu \mathrm{m})$ Iowa River water $(\mathrm{pH} \sim 8.5)$. Similar to benoxacor photolysis at $\mathrm{pH} 9$, Product $\mathrm{D}$ is a major product at $\mathrm{pH} 8.5$ and is only observed at these more alkaline conditions. 

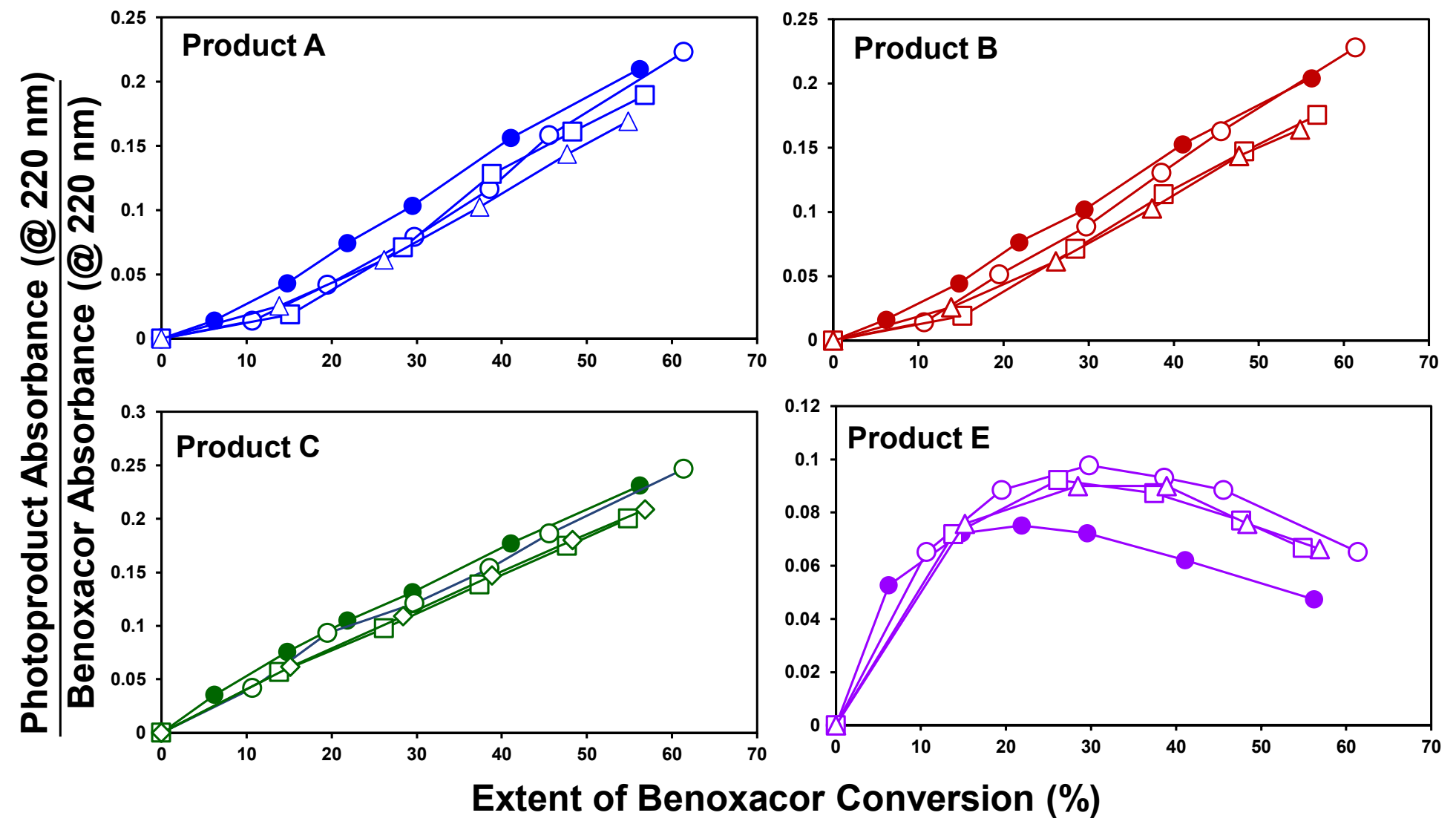

Figures S6. Benoxacor photoproduct formation in phosphate-buffered aqueous solutions at pH 9 both in the presence (open symbols; three replicates shown) and absence (solid symbols) of oxygen. Deoxygenated systems were conducted under an overpressure of $\mathrm{N}_{2}$ after sparing the benoxacor solution with $\mathrm{N}_{2}$ for 1 hour prior to irradiation. Plots show the peak area response for Products A, B, C and $\mathrm{E}$ (as measured by absorbance at $220 \mathrm{~nm}$ ) after normalization to the initial peak area of benoxacor (also measured by absorbance at 220 $\mathrm{nm}$ ) as a function of reaction progress (expressed as the percent of benoxacor conversion). 

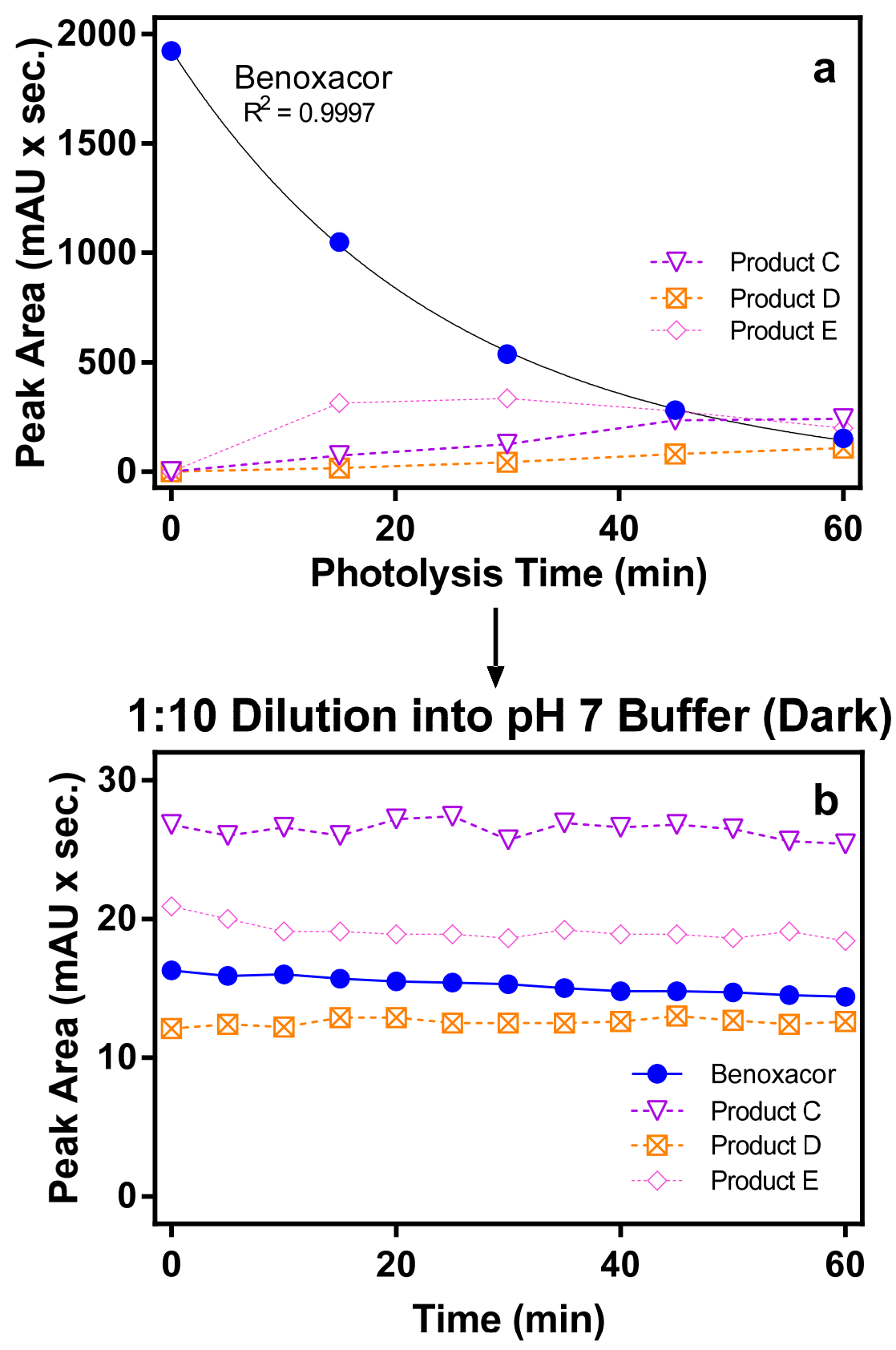

Figure S7. (a) Photolysis of $100 \mu \mathrm{M}$ benoxacor in acetonitrile. (b) Subsequently, a $2 \mathrm{~mL}$ aliquot of the photoproduct mixture was spiked into $20 \mathrm{~mL}$ of $\mathrm{pH} 7$ buffer, where the solution was placed in the dark (to quench photolysis) and the aqueous (thermal) stability of photoproducts was monitored. Products C, D, and E were stable over this time period, as was benoxacor, and formation of Products A and B was not observed. 


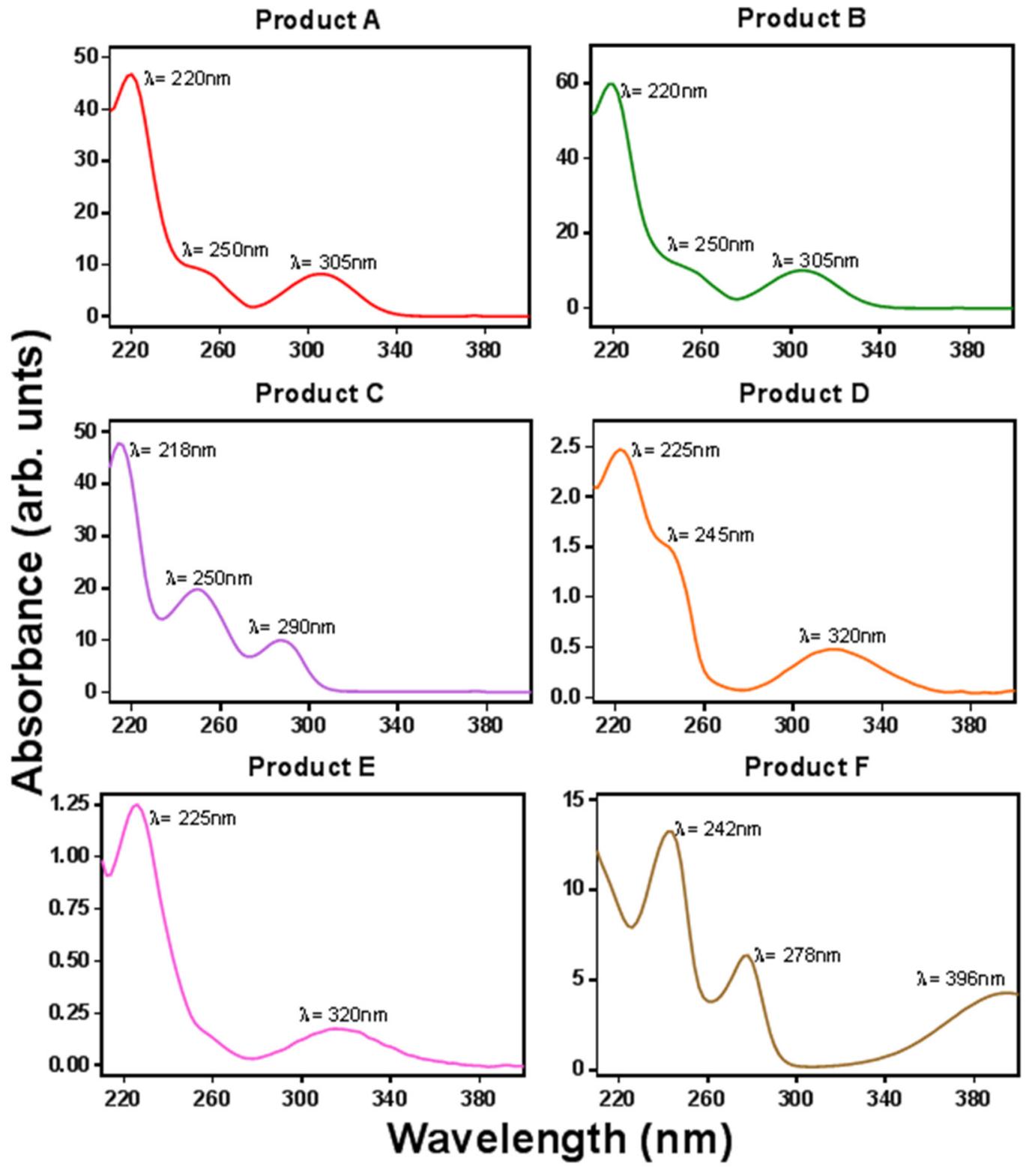

Figure S8. UV/visible absorbance spectra of benoxacor photoproducts as measured via HPLCDAD. Local maxima are noted. 


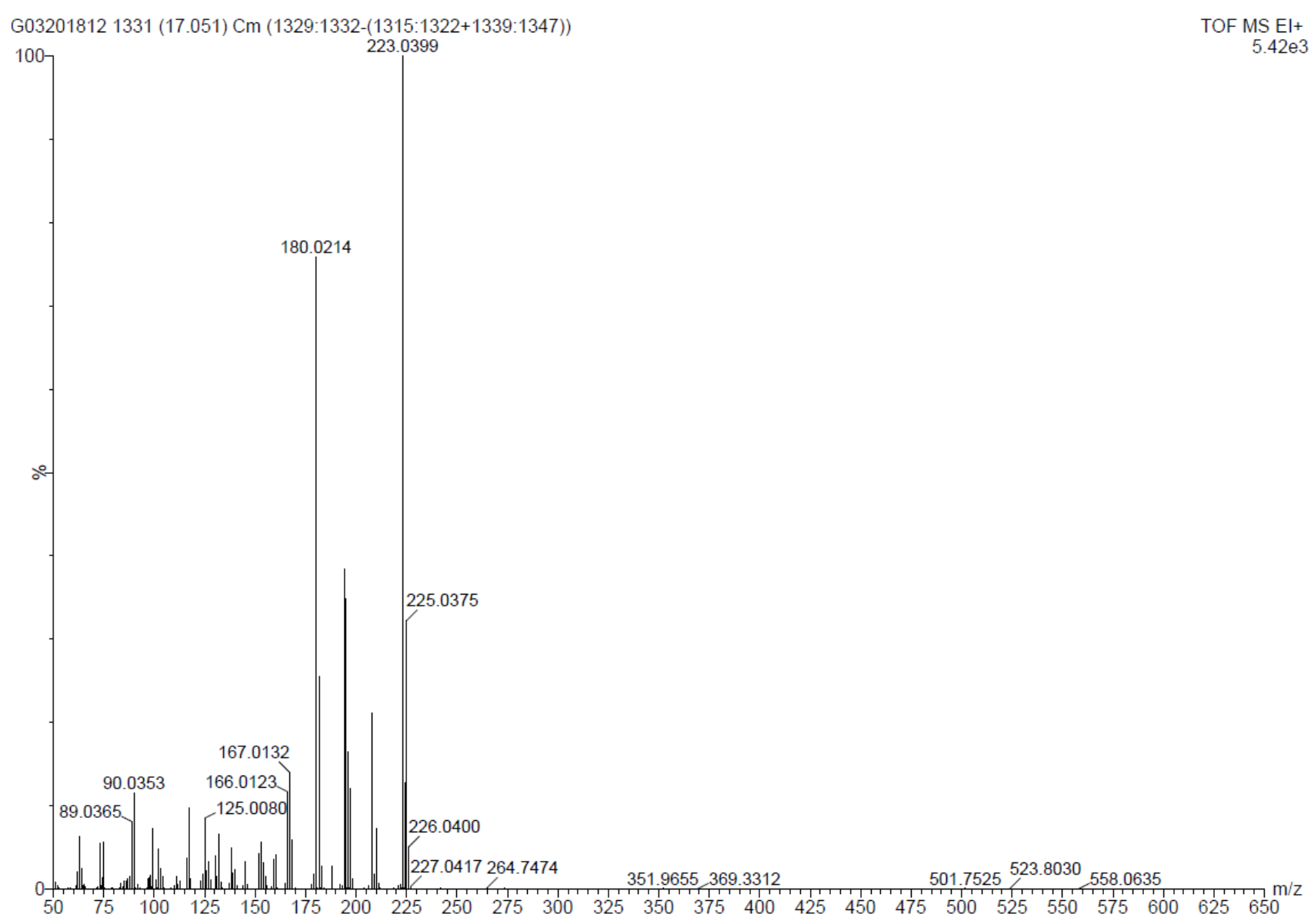

Figure S9. HRMS spectrum of benoxacor photolysis Product E. 


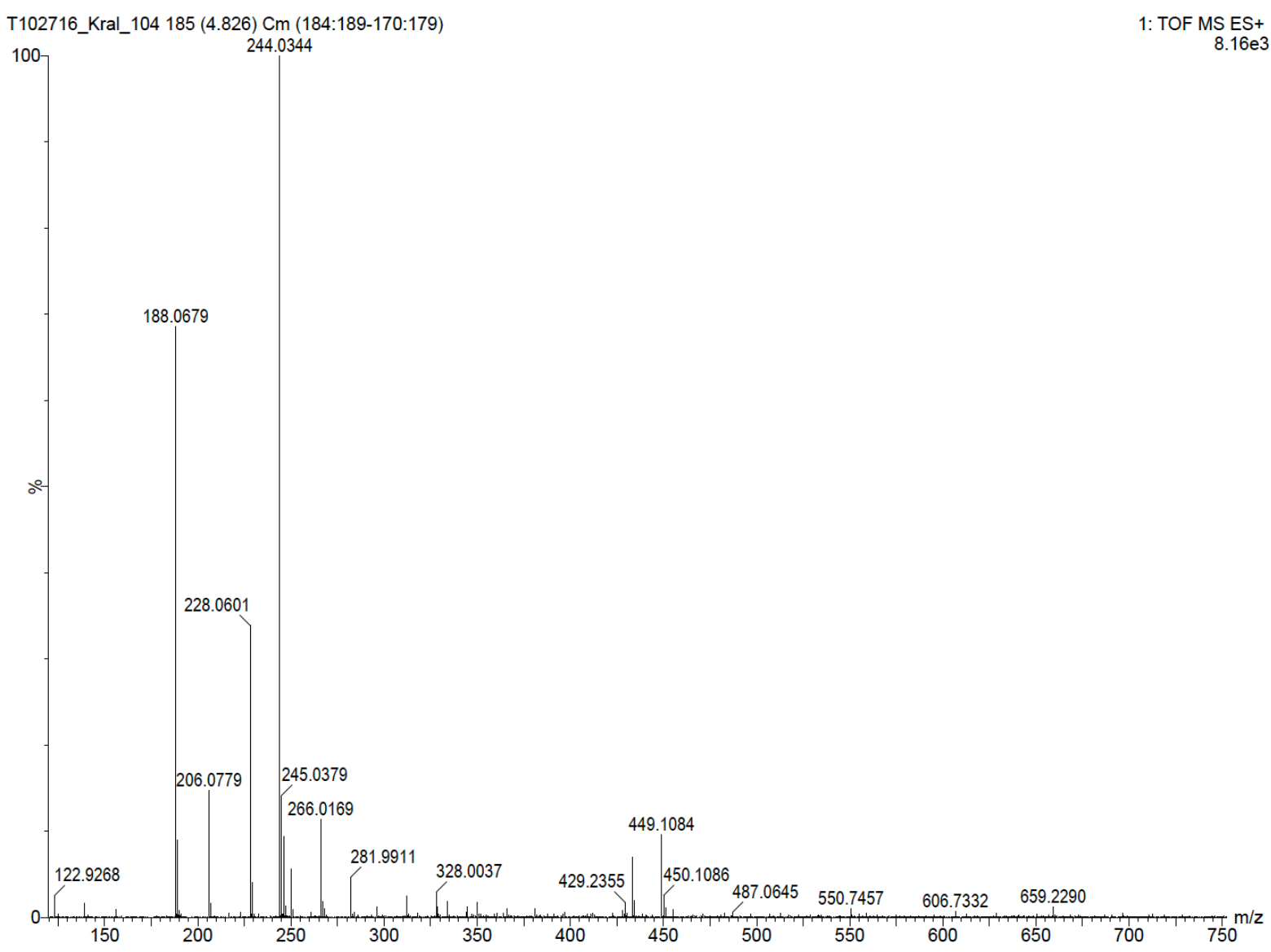

Figure S10. HRMS spectrum of benoxacor photolysis Product A. Identical spectra were also observed for Products B and C. 

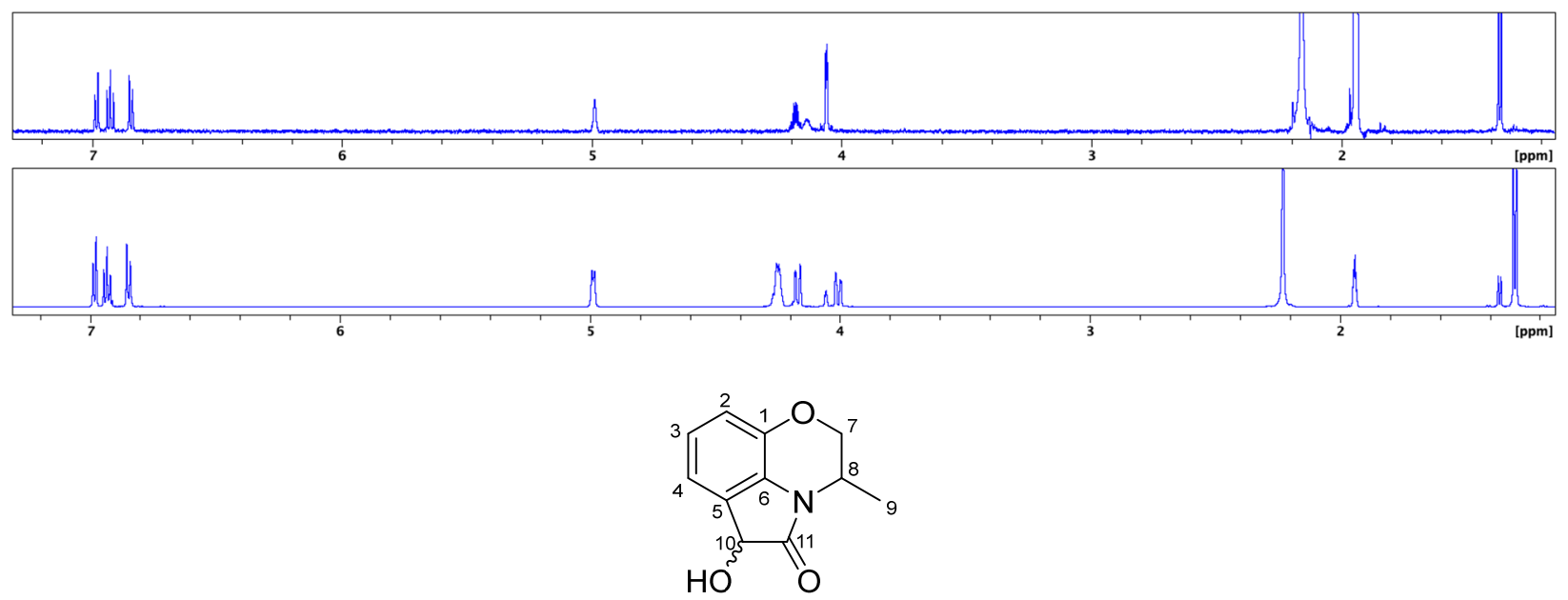

Product A/B

Figure S11. ${ }^{1} \mathrm{H}$ NMR spectra of benoxacor photolysis diastereomeric Products A and B in ACNd3 (600 MHz), along with their proposed structures.

Table S3. ${ }^{1} \mathrm{H}$ data for benoxacor photolysis diastereomeric Products A and B in ACN-d3 (600 $\mathrm{MHz}$ ).

\begin{tabular}{|c|c|c|}
\hline \multicolumn{3}{|c|}{ Products A and B } \\
Proton & $\delta_{\mathrm{H}}$ mult. $(\mathrm{J}$ in Hz) \\
\hline 2 & $6.84 \mathrm{~d}(8.0)$ & $6.85 \mathrm{~d}(8.0)$ \\
\hline 3 & $6.92 \mathrm{t}(8.0)$ & $6.93 \mathrm{t}(8.0)$ \\
\hline 4 & $6.98 \mathrm{~d}(8.0)$ & $6.98 \mathrm{~d}(8.0)$ \\
\hline 7 & $4.05 \mathrm{~m}$ & $4.01 \mathrm{~m}$ \\
\hline & $4.06 \mathrm{~m}$ & $4.16 \mathrm{~m}$ \\
\hline 8 & $4.18 \mathrm{~m}$ & $4.25 \mathrm{~m}$ \\
\hline 9 & $1.36 \mathrm{~d}(6.7)$ & $1.30 \mathrm{~d}(6.7)$ \\
\hline 10 & $4.99 \mathrm{~s}$ & $4.99 \mathrm{~d}(6.2)$ \\
\hline $\mathrm{O}-\mathrm{H}$ & $4.14 \mathrm{bs}$ & $4.27 \mathrm{bs}$ \\
\hline
\end{tabular}



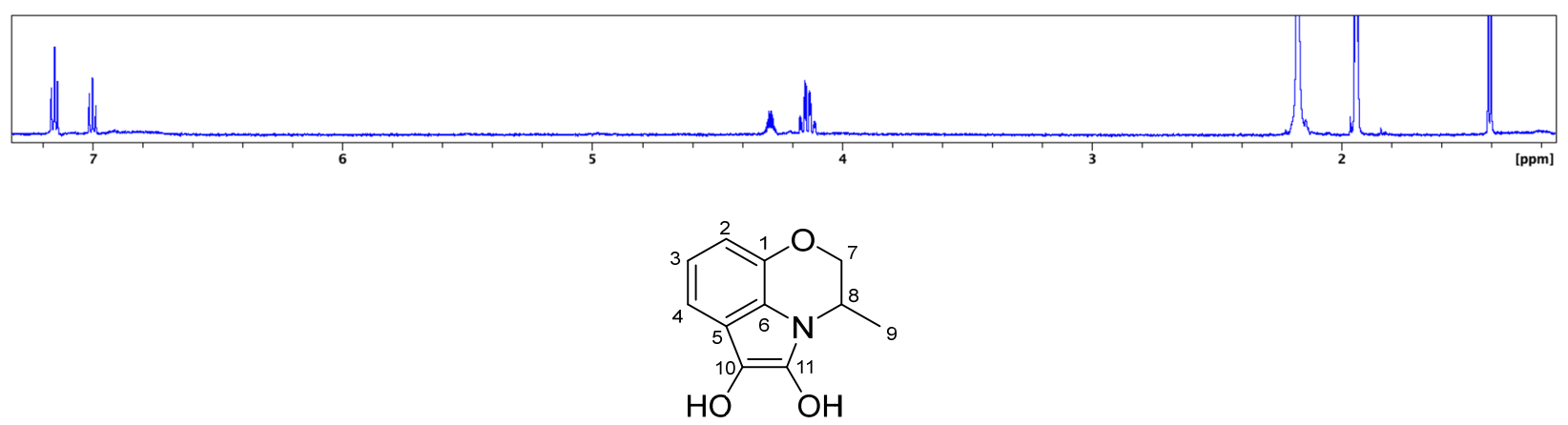

Product C

Figure S12. ${ }^{1} \mathrm{H}$ NMR spectrum of benoxacor photolysis Product C in ACN-d3 (600 MHz), along with its proposed structure.

Table S4. ${ }^{1} \mathrm{H}$ data for benoxacor photolysis Product $\mathrm{C}$ in ACN-d3 (600 MHz).

\begin{tabular}{|c|c|}
\hline & Product $\mathrm{C}$ \\
Proton & $\delta_{\mathrm{H}}$ mult. $(\mathrm{J}$ in $\mathrm{Hz})$ \\
\hline 2 & $7.15 \mathrm{dd}(7.0,0.8)$ \\
\hline 3 & $7.00 \mathrm{t}(7.8)$ \\
\hline 4 & $7.16 \mathrm{dd}(7.8,0.8)$ \\
\hline 7 & $4.12 \mathrm{~m}$ \\
\hline 8 & $4.16 \mathrm{~m}$ \\
\hline 9 & $4.29 \mathrm{~m}$ \\
\hline $\mathrm{O}-\mathrm{H}$ & $1.41 \mathrm{~d}(6.7)$ \\
\hline $\mathrm{O}-\mathrm{H}$ & $6.81 \mathrm{bs}$ \\
\hline
\end{tabular}

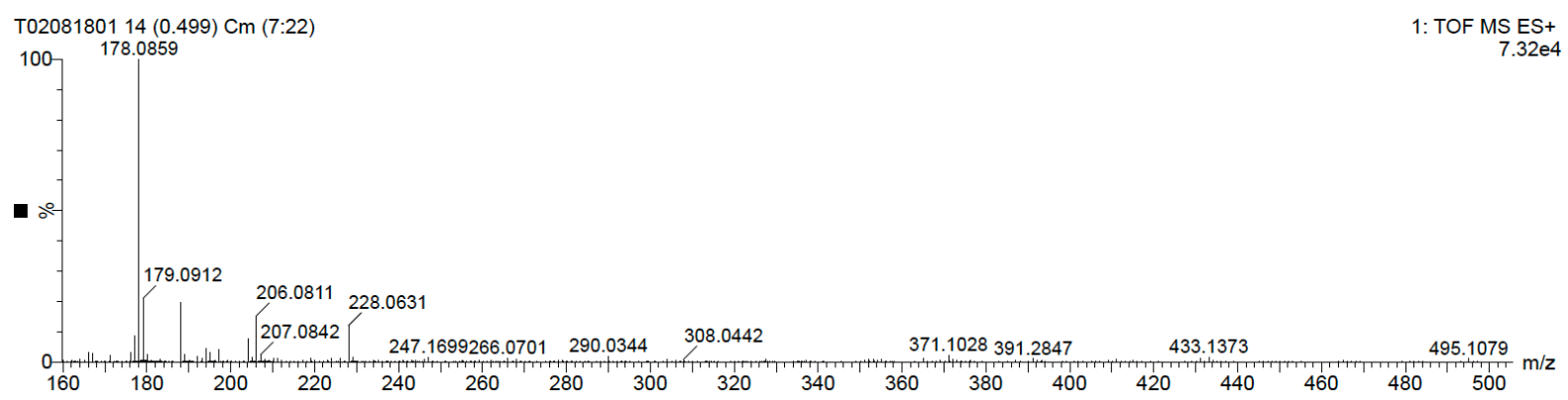

Figure S13. HRMS spectrum of benoxacor photolysis Product F. We attribute the $m / z$ values of 206.0811 (with Na adduct of 228.0631), which correspond to PA/PB/PC, to the presence of minor impurities in the isolated fraction. Because this MS chromatogram was generated from direct injection of the isolated sample, all materials present in the sample generate a corresponding signal. 


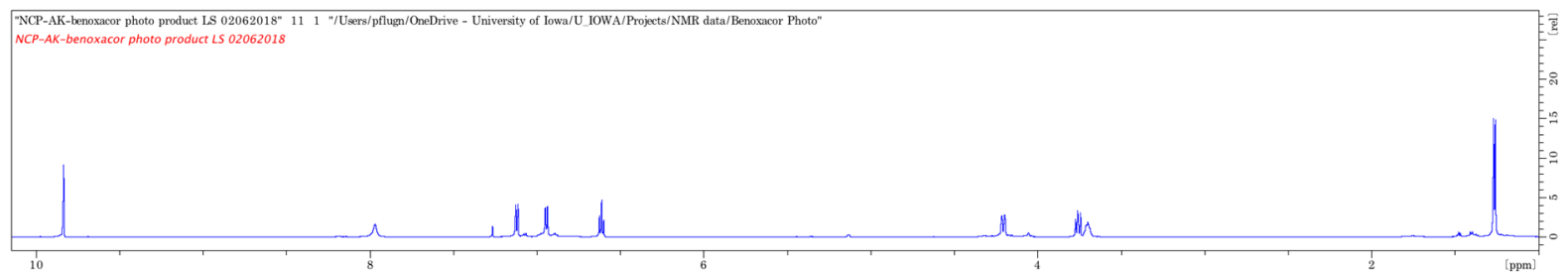

Figure S14. ${ }^{1} \mathrm{H}$ NMR spectrum of benoxacor photolysis Product $\mathrm{F}$ in $\mathrm{CDCl}_{3}(600 \mathrm{MHz})$.

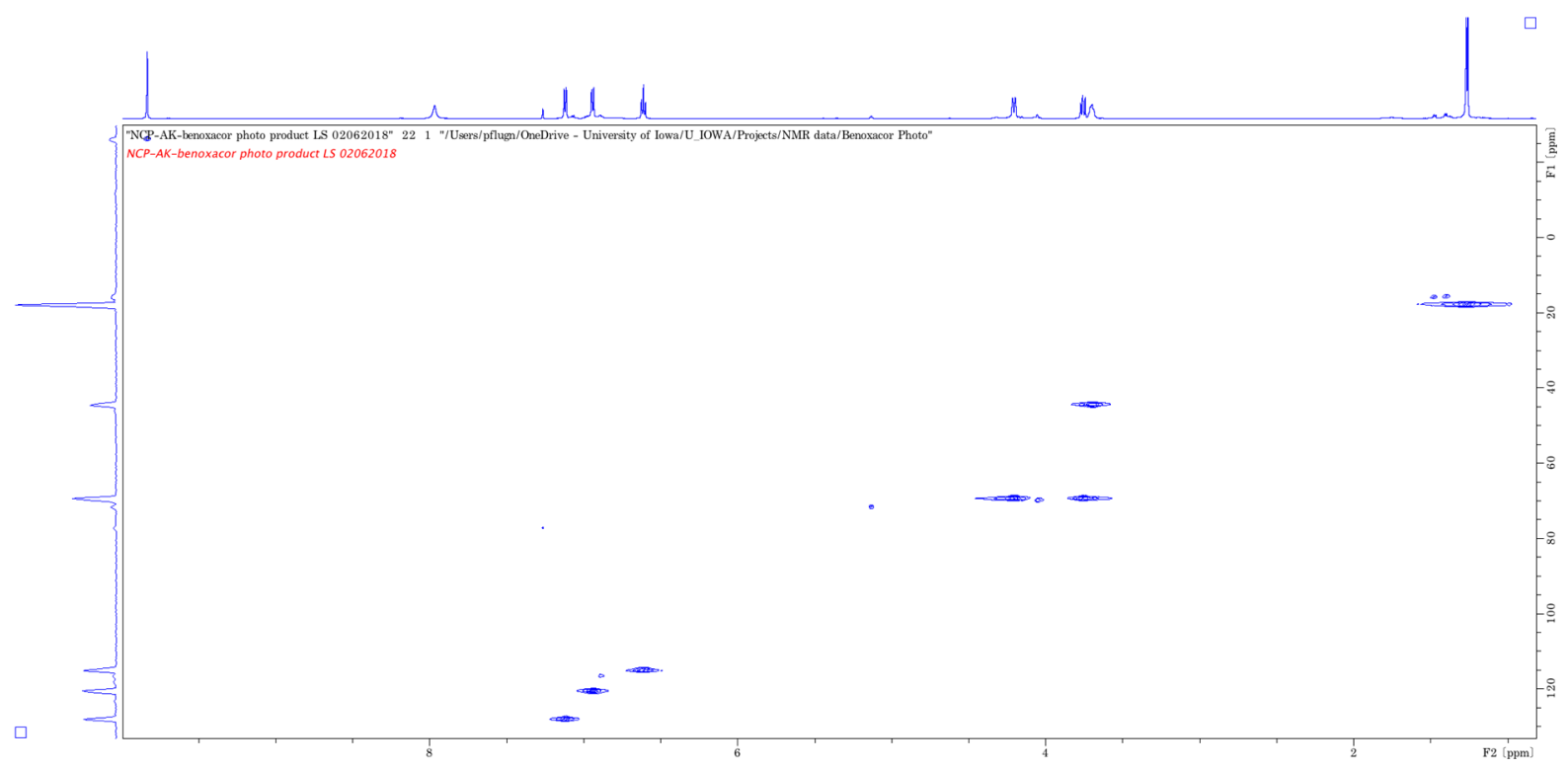

Figure S15. HSQC spectrum of benoxacor photolysis Product $\mathrm{F}$ in $\mathrm{CDCl}_{3}(600 \mathrm{MHz})$.

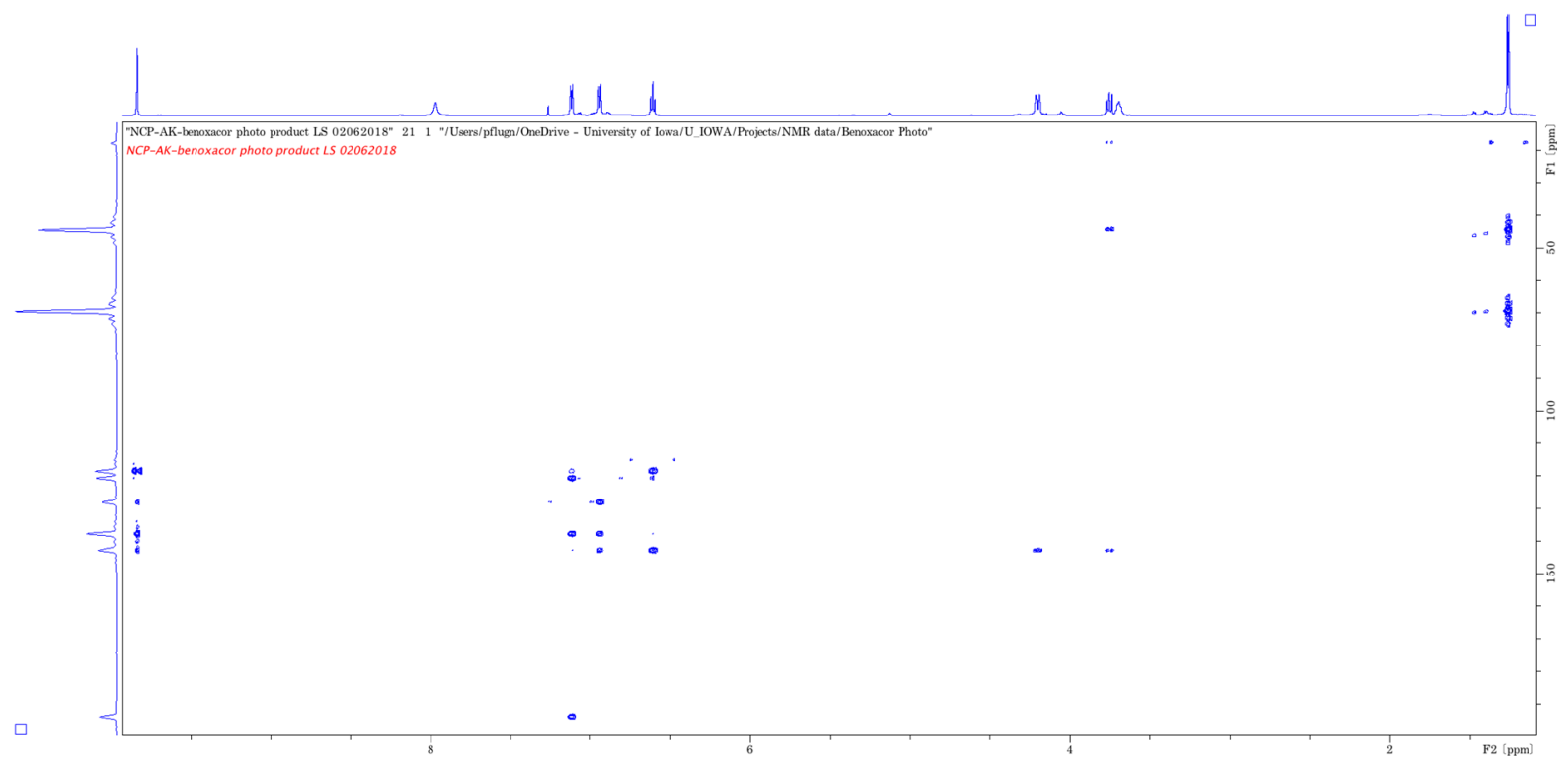

Figure S16. HMBC spectrum of benoxacor photolysis Product $\mathrm{F}$ in $\mathrm{CDCl}_{3}(600 \mathrm{MHz})$. 
Table S5. ${ }^{1} \mathrm{H}$ and ${ }^{13} \mathrm{C}$ NMR data and HMBC correlations for benoxacor photolysis Product $\mathrm{F}$ in $\mathrm{CDCl}_{3}(600 \mathrm{MHz})$.

\begin{tabular}{|c|c|c|c|c|}
\hline Proton & $\delta_{H}$ mult. $(J$ in $\mathrm{Hz})$ & $\mathrm{H \# \rightarrow C \#}$ & carbon & $\delta_{C}$ \\
\hline 2 & $6.94 \mathrm{~d}(7.8)$ & $1,4,6$ & 1 & 142.9 \\
\hline 3 & $6.61 \mathrm{t}(7.8)$ & $1,2,5$ & 2 & 120.7 \\
\hline 4 & $7.12 \mathrm{~d}(7.8)$ & $2,5,6,10$ & 3 & 115.3 \\
\hline \multirow[t]{2}{*}{7} & $3.76 \mathrm{dd}(7.5,10.3)$ & $1,8,9$ & 4 & 128.3 \\
\hline & $4.2 \mathrm{~m}$ & & 5 & 118.7 \\
\hline 8 & $3.69 \mathrm{~m}$ & 7,9 & 6 & 138.1 \\
\hline 9 & $1.26 \mathrm{~d}(6.4)$ & 7,8 & 7 & 69.5 \\
\hline 10 & $9.83 \mathrm{~s}$ & $4,5,6$ & 8 & 44.6 \\
\hline \multirow[t]{2}{*}{$\mathrm{N}-\mathrm{H}$} & 7.96 bs & & 9 & 18.0 \\
\hline & & & 10 & 194.2 \\
\hline
\end{tabular}

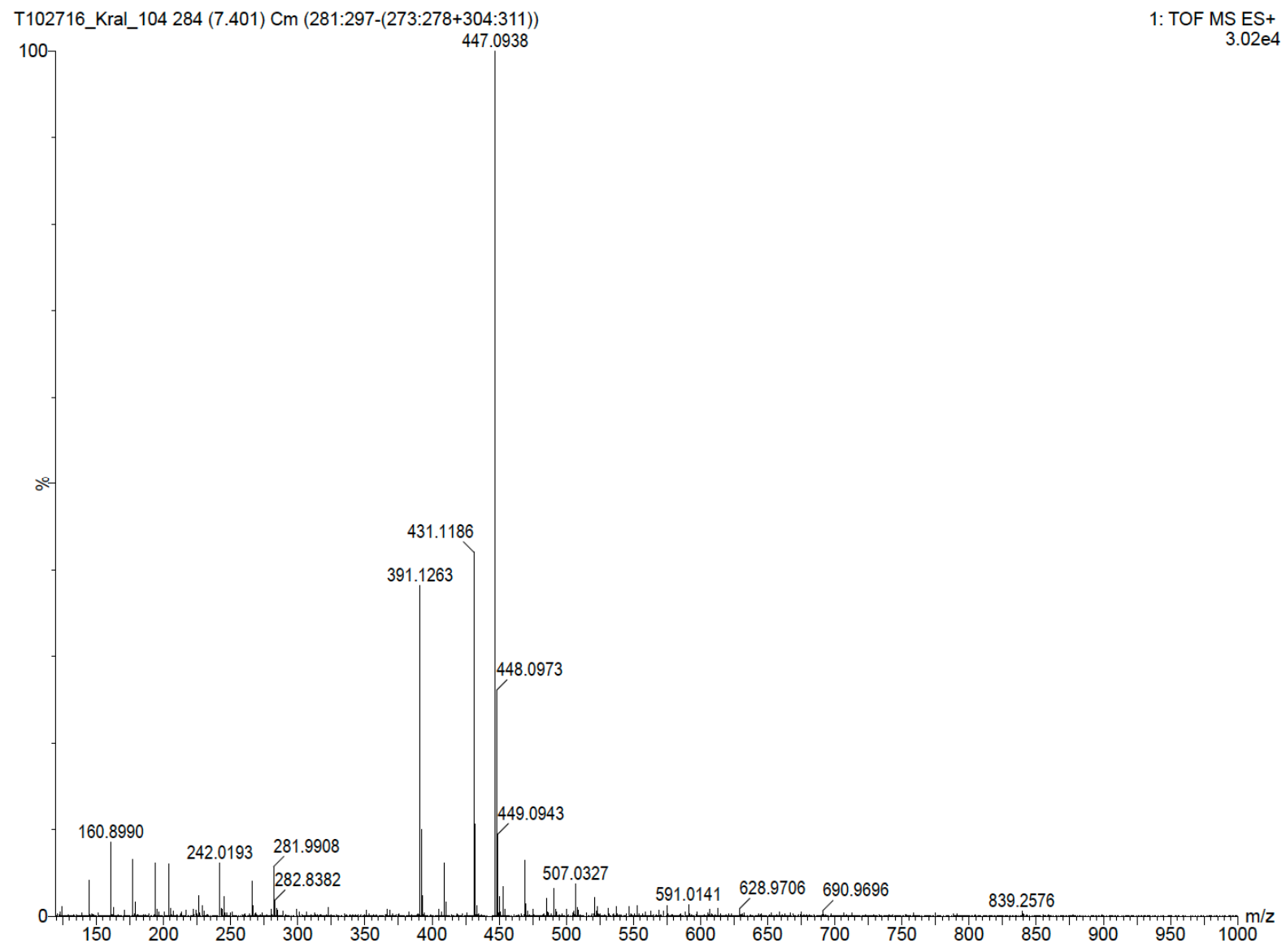

Figure S17. HRMS spectrum of benoxacor photolysis Product D. 


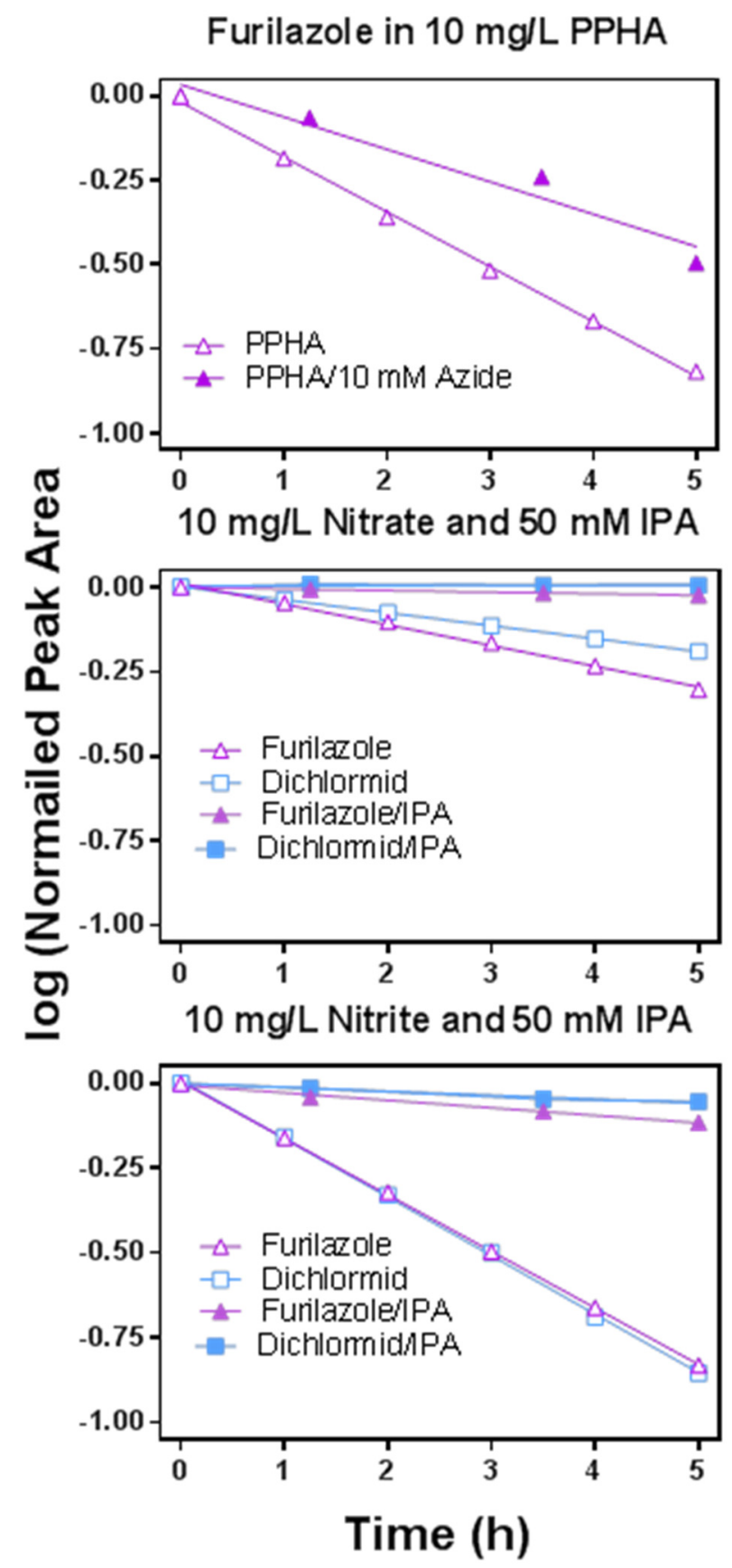

Figure S18. Semi-log concentration versus time plots for furilazole and dichlormid in the presence and absence of selective ROS quenchers including (top) azide for quenching of ${ }^{1} \mathrm{O}_{2}$ in irradiated PPHA systems, and isopropyl alcohol (or IPA) for quenching of radicals (e.g., ${ }^{\bullet} \mathrm{OH}$ ) in (middle) nitrate and (bottom) nitrite systems. 

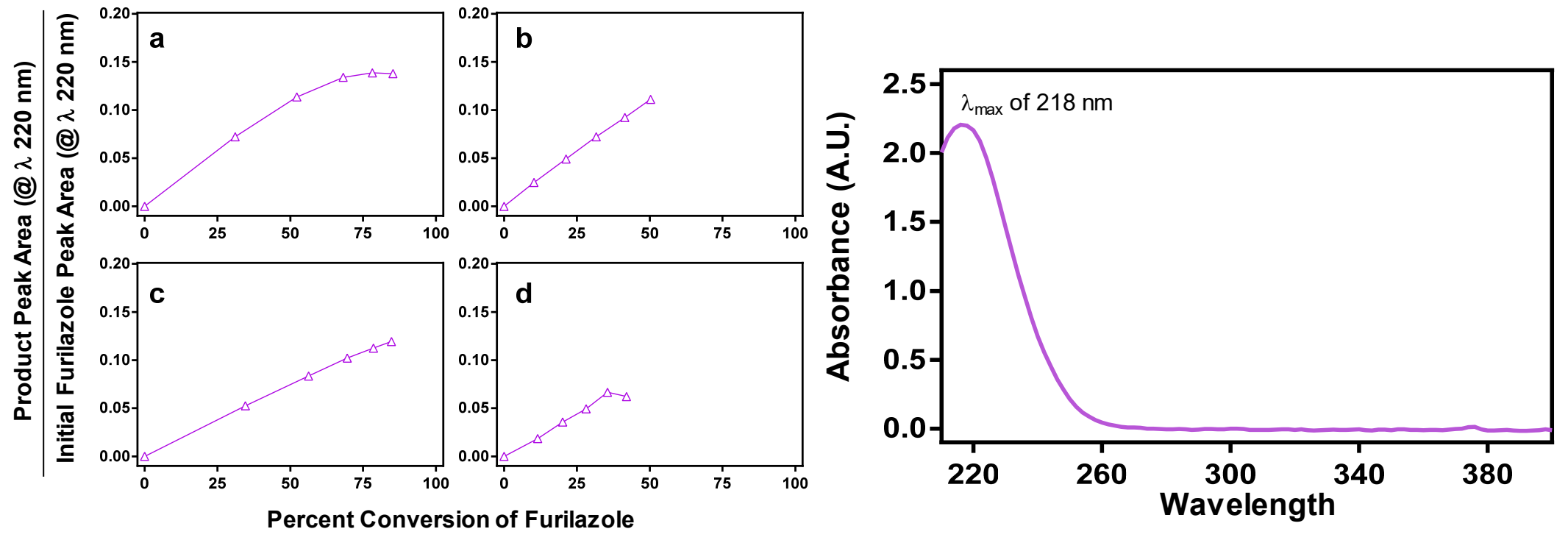

Figure S19. Yield plots for the product detected during furilazole indirect photolysis in (a) $\mathrm{NO}_{2}^{-}$, (b) $\mathrm{NO}_{3}^{-}$, (c) PPHA, and (d) SRHA. (e) Also provided is the UV/vis absorbance spectrum for this species, which is more polar than furilazole based on its elution time on our $\mathrm{C}_{18}$ HPLC column (product retention time of 3.9 min versus $9.8 \mathrm{~min}$ for furilazole). 

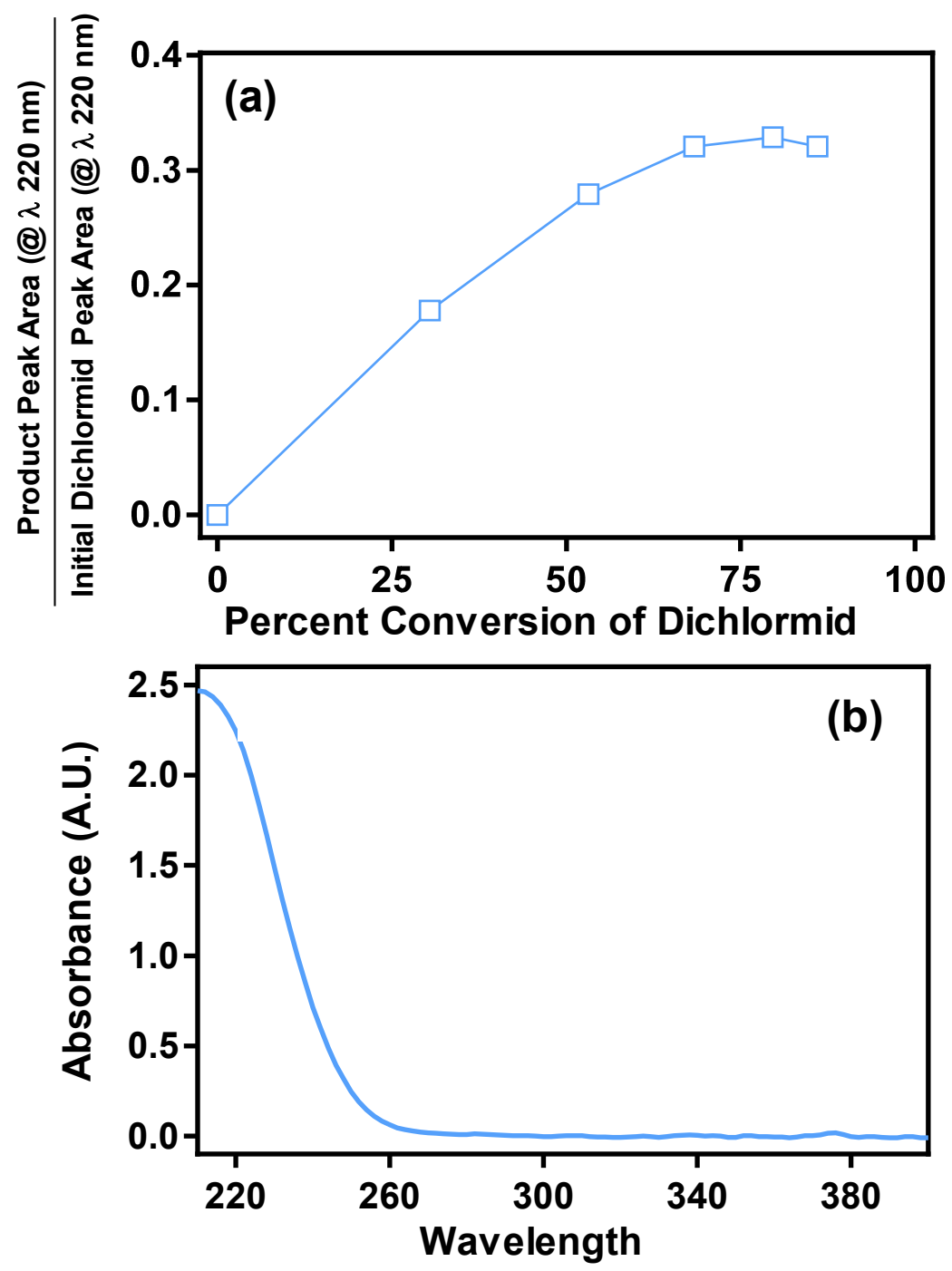

Figure S20. Yield plot for the product detected during dichlormid indirect photolysis in $10 \mathrm{mg} / \mathrm{L}$ $\mathrm{NO}_{2}^{-}$. (b) Also provided is the UV/vis absorbance spectrum for this species, which is more polar than dichlormid based on its elution time on our $\mathrm{C}_{18}$ HPLC column (product retention time of 5.4 min versus $8.8 \mathrm{~min}$ for dichlormid). 

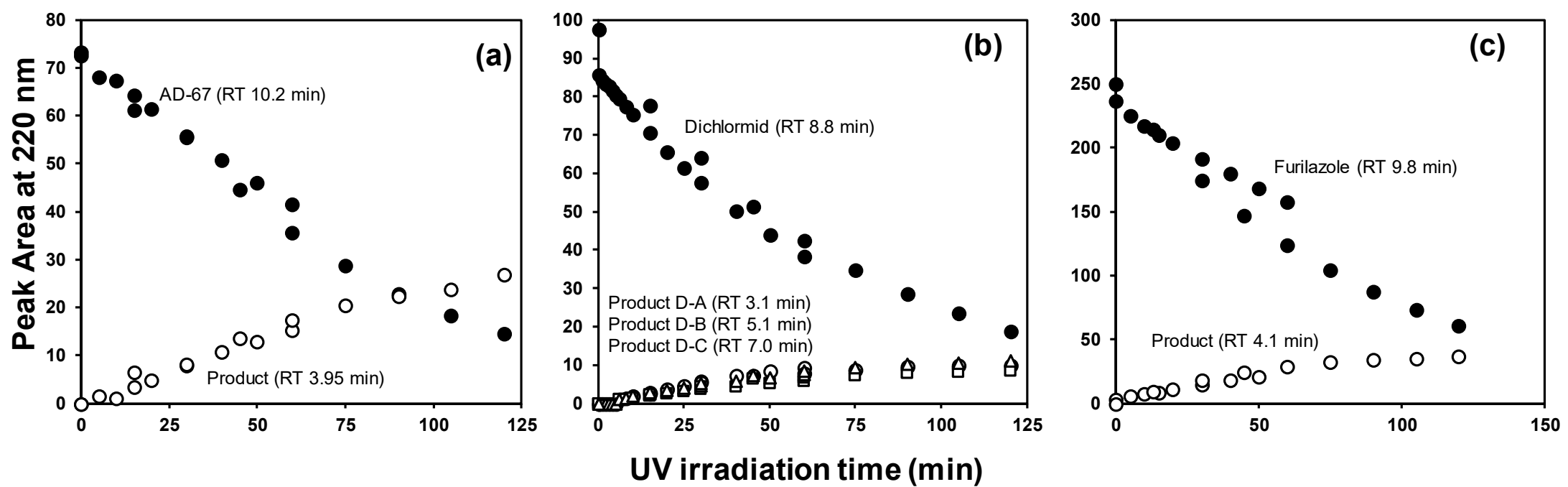

Figure S21. LC-DAD peak area (based on absorbance at $220 \mathrm{~nm}$ ) versus time plots for AD-67, dichlormid, and furilazole in $\mathrm{pH} 7$ buffer under a $200 \mathrm{~W} \mathrm{Mg}(\mathrm{Xe})$ lamp with a $250 \mathrm{~nm}$ cut-on filter. Data for benoxacor is not shown, as the UV light only sped up the rate of transformation but did not alter the identify or yield of products. Products detected by LC-DAD at $220 \mathrm{~nm}$ are shown, and were generally more polar (based on $\mathrm{C}_{18}$ retention times provided) than the corresponding parents. Additional efforts to further characterize these products by LC- and GC-HR-ESI-TOFMS were not successful, although the products for dichlormid were ultimately compared to reference standards based upon the UV-photolysis pathway proposed by Abu-Qare and Duncan. ${ }^{6}$ 


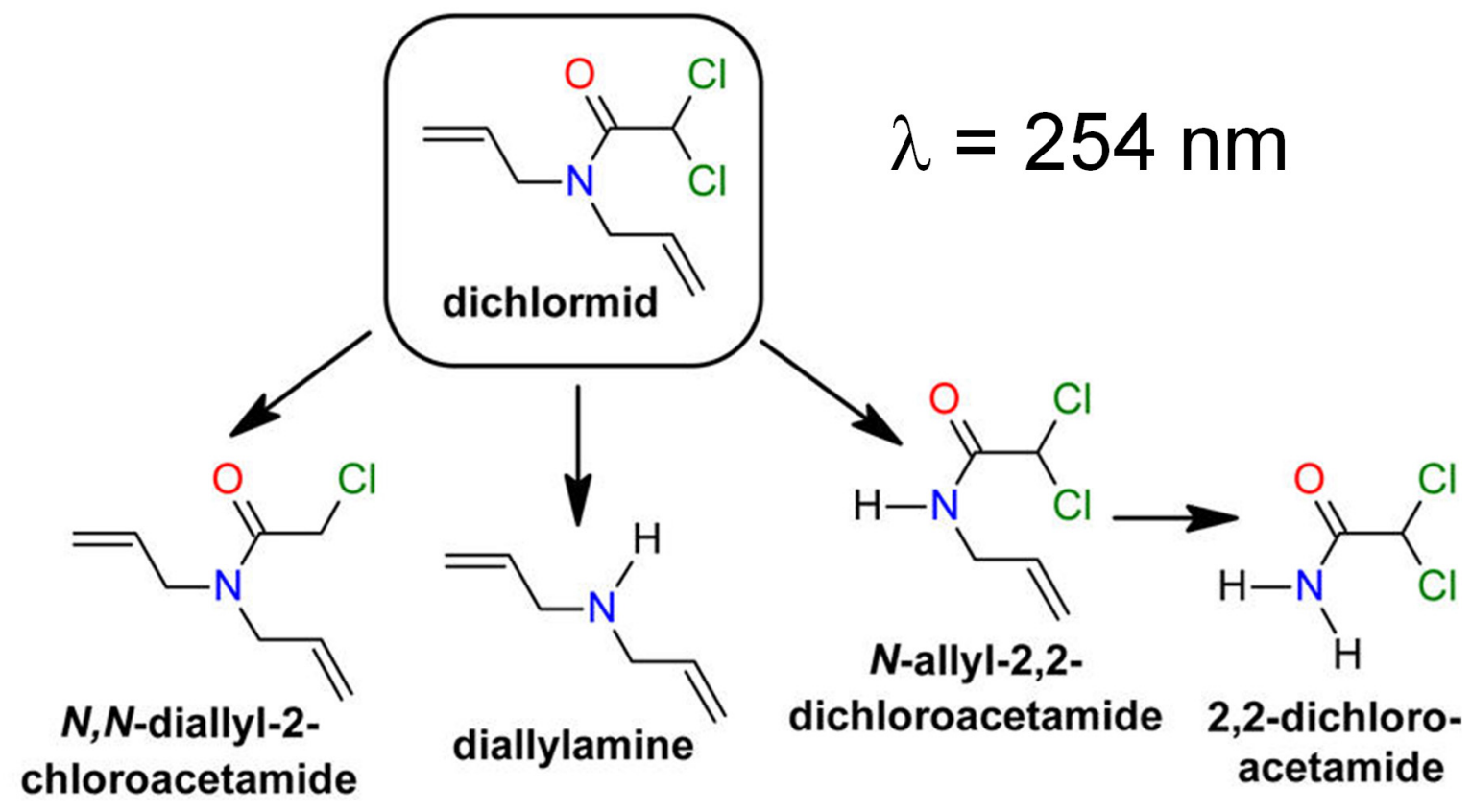

Figure S22. Photolysis pathway proposed by Abu-Qare and Duncan ${ }^{7}$ for dichlormid under 254 $\mathrm{nm}$ light. Figure adapted from Sivey et al. ${ }^{8}$ 


\section{Literature Cited}

1. Leifer, A., The Kinetics of Environmental Aquatic Photochemistry: Theory and Practice. American Chemical Society: Washington, DC, 1988.

2. Schwarzenbach, R. P.; Gschwend, P. M.; Imboden, D. M., Environmental organic chemistry. In 2nd ed.; Wiley,: Hoboken, N.J., 2003; p 1 online resource (1329 p.).

3. Laszakovits, J. R.; Berg, S. M.; Anderson, B. G.; O’Brien, J. E.; Wammer, K. H.; Sharpless, C. M., p-Nitroanisole/Pyridine and p-Nitroacetophenone/Pyridine Actinometers Revisited: Quantum Yield in Comparison to Ferrioxalate. Environmental Science \& Technology Letters 2017, 4, (1), 11-14.

4. Qu, S.; Kolodziej, E. P.; Cwiertny, D. M., Phototransformation Rates and Mechanisms for Synthetic Hormone Growth Promoters Used in Animal Agriculture. Environmental Science \& Technology 2012, 46, (24), 13202-13211.

5. Werner, J. J.; McNeill, K.; Arnold, W. A., Environmental photodegradation of mefenamic acid. Chemosphere 2005, 58, (10), 1339-1346.

6. ASTM International. ASTM G173-03(2012) Standard Tables for Reference Solar Spectral Irradiances: Direct Normal and Hemispherical on $37^{\circ}$ Tilted Surface. West Conshohocken, PA; ASTM International, 2012. doi: https://doi.org/10.1520/G017303R12.

7. Abu-Qare, A. W.; Duncan, H. J., Photodegradation of the herbicide EPTC and the safener dichlormid, alone and in combination. Chemosphere 2002, 46, (8), 1183-1189.

8. Sivey, J. D.; Lehmler, H.-J.; Salice, C. J.; Ricko, A. N.; Cwiertny, D. M., Environmental Fate and Effects of Dichloroacetamide Herbicide Safeners: "Inert" yet Biologically Active Agrochemical Ingredients. Environmental Science \& Technology Letters 2015, 2, (10), 260-269. 